\title{
Pregnancy Tradition "Ngapati" in Javanese Society Based on Perspective of the Qur'an and Hadith
}

\author{
H Aliyah ${ }^{1}$, R Jannah ${ }^{2}$, N Azizah ${ }^{3}$ \\ ${ }^{1}$ Islamic Building School of Jagad Alimussirry Surabaya, Indonesia \\ ${ }^{23}$ Science Department, Universitas Negeri Surabaya \\ Email: hima.kimia99@gmail.com
}

\begin{abstract}
Traditions and customs are an inseparable part of Javanese society. Traditipns four months of pregnancy or known as ngapati is one of the traditions carried out by the Javanese people until now. But nowadays, the tradition of ngapati is much abandoned by the Society. Some people consider the tradition to be out of order in the Qur'an and the Hadith, and even prohibit it. By comparing various exposures from the literature, the authors analyze, identify and review many literatures, this article discusses in depth the tradition of ngapati done by the community and its relation in the Qur'an and Hadith. Research reveals that the tradition of the regent is not in conflict with the Qur'an and the Hadith.
\end{abstract}

Keywords: ngapati; period of pregnancy; culture; Islam

\section{INTRODUCTION}

Javanese society is a society that is rich in traditions and customs (in other terms it is called slametan taken from Salamah, Arabic language, which is interpreted as a condition free from unwanted events) [1]. Slametan is a traditional ceremony conducted by a person or family or village and is attended by the surrounding community with the aim that slamet or nothing dangerous happens [24]. For Javanese people, carrying out a custom or slametan is a symbol of the level of obedience of a servant to his Lord and preventive action from various kinds of calamities and disasters. This is done with the aim of gaining the security of life physically and spiritually, asking for safety and blessing and fulfilling his spiritual needs, eling marang purwa daksina [9]. The tradition originated from the beliefs held for generations by his ancestors.

Since Islam entered Java, the preachers, among others, wali songo, were open to Javanese culture and traditions that did not conflict with Islamic teachings [10]. One of them is the tradition of ngapati or slametan ceremony for four months of pregnancy. The ngapati traditional ceremony is hereditary and continues from one generation to another which is marked by the making of jenang sumsum. In its development, the ngapati ceremony has been cultured with Islamic values. The goal is to pray and ask for safety for the baby with the reading of the Qur'an and glorify the Name of Allah SWT.

Nowadays, the tradition of ngapati is much abandoned by the Society. Some people consider the tradition to be out of order in the Qur'an and the Hadith, and even prohibit it.

Research reveals that the tradition of ngapati is well received in many comunities and and is practiced throughout the fetus when it is four months old. The practice of ngapati tradition is considered as one of the discussions discussed in the Hadith of the 
Prophet and based on the Qur'an and the Hadith. [11-13]

This paper aims to discuss in depth why the tradition of ngapati still appears and is carried out continuously in Javanese society; whether there is a link between tradition ngapati with Qur'an and Hadits Prophet experiencing transmission along with the growing age.

\section{METHOD}

The method used in this study is the literature review. Literatures used include books, articles, and trusted sites. By comparing various exposures from the literature, the authors analyze, identify and review to produce a more objective view of ngapati traditions.

\section{RESULT AND DISCUSSION}

"Ngapati" Pregnancy Tradition Ceremony in Javanese Society

\section{A. The tradition of fetal slametan in pre- Islamic times}

The beliefs of Animism, Dynamism, Hinduism and Buddhism are beliefs that were embraced by the Javanese people before the coming of Islam. Bakker states that belief in spirit (animism) and Belief in power (dynamism) are Native Indonesian religions [14] .

Adherents of Animism, Dynamism, Hinduism and Buddhism perform rituals using seseji (offerings) and spells. Offerings are offered to the spirits of ancestors or extraordinary powers that are believed to help or harm humans. Rituals are held to avoid disaster or disaster and seek safety (Selamet). The term slametan is generally used by the Javanese people who hold rituals by praying to be given salvation in their lives.

At the pregnancy slametan ceremony, there are symbols that are used, among others, pregnant women are bathed by changing batik cloth 7 times. The names of the batik cloth used during the splash water also contain meaning and hope, such as the Sido luhur style batik (being a person who is glorified), sidomukti (being a respectable person). In the ceremony also used two young ivory coconuts with Kamajaya and ratih paintings. This painting contains the hope that the child in the womb if the male sex will look handsome like the god Kamajaya, whereas if the woman will look beautiful like the goddess of training.

The dishes that are served vary depending on the age of the fetus in the womb. At the age of three months, the dishes include: clear jenang, jenang marrow, rice punar and fried fish. At the age of 4 months of the fetus: ketupat with warm, rice cone with lent, and sticky rice with 4 kinds of enten-enten. At the age of 7 months of the fetus: yellow rice.

At the 7-month-old fetal slametan ceremony, pregnant women wash their bodies with green coconut water whose coconut shells are painted two pictures of wayang figures of different sexes. At the ceremony a puppet show must be held by taking a story about the life and adventure of a prince descended from the god Barata Brama.

If a woman has given birth to a baby, then the epidermis is immediately cut with a sharp knife made of bamboo, wrapped in a piece of paper inscribed with Javanese letters, then placed in a clay barrel to be buried in the ground. The buried placard is illuminated with ublik lights (lamps made from gas oil and ignited by fire), covered with bamboo baskets and decorated with pandan leaves. The lamp is kept burning until the baby's navel cord is released. The placenta is symbolized as sedulur from the newborn baby [15].

Such is the description of the tradition of pregnancy ceremonies in pre-Islamic times. After Islam spread in Java, there was a mixture of pre-Islamic belief elements (Animism, Dynamism, Hinduism and Buddhism) with elements of Islam that fostered syncretism. 
In the syncretism process there is a mixture of pre-Islamic elements with Islam so that different abstract forms are obtained to find harmony and balance. This syncretism process gave birth to two groups of Islam, namely Jawi Islam (Belief in Allah, the Apostle and also supernatural beings and supernatural powers) and puritanical Islam (practicing Islam according to the guidance of the Prophet).

\section{B. The tradition of fetal slametan during Islam}

After Islam entered Java, the missionaries and guardians of Songo were open to Javanese culture, so that Islam was easily accepted by the community. This is indicated by the existence of various cultures and traditions of Javanese society which are entered with Islamic elements.

The pregnancy ceremony of the regent who initially used recitation of mantras and puppet shows was replaced with recitations of the Qur'an, the Prophet's prayers and prayers of kindness. The food served is coupled with diamonds (kupat) which symbolizes the word ngupati. The term ngupati is then more popular with walimatul haml.

The tradition of the regent is generally carried out by the majority of Javanese people. The reading of the Qur'an which is commonly read at the event of the regent is QS. Yusuf, QS. Maryam, QS. Luqman and QS. Yasin With the hope that if the baby is born someday it will be sholih or sholihah and also handsome as the Prophet Yunus, Syaidah Maryam and Luqman as told in the Qur'an, and obtain the blessing of salvation by reading the QS. Yasin.

The prayer of what is being said in walimatul haml, in the quotation from the work of the Standing Committee Ta'lif Old Gate Library, Pondok Pesantren Lirboyo) in the book Entering the Gate of Heaven; Collection of Salafus Salih Prayers (Kediri: Old Gate Library, 2010), p. 119: [19]

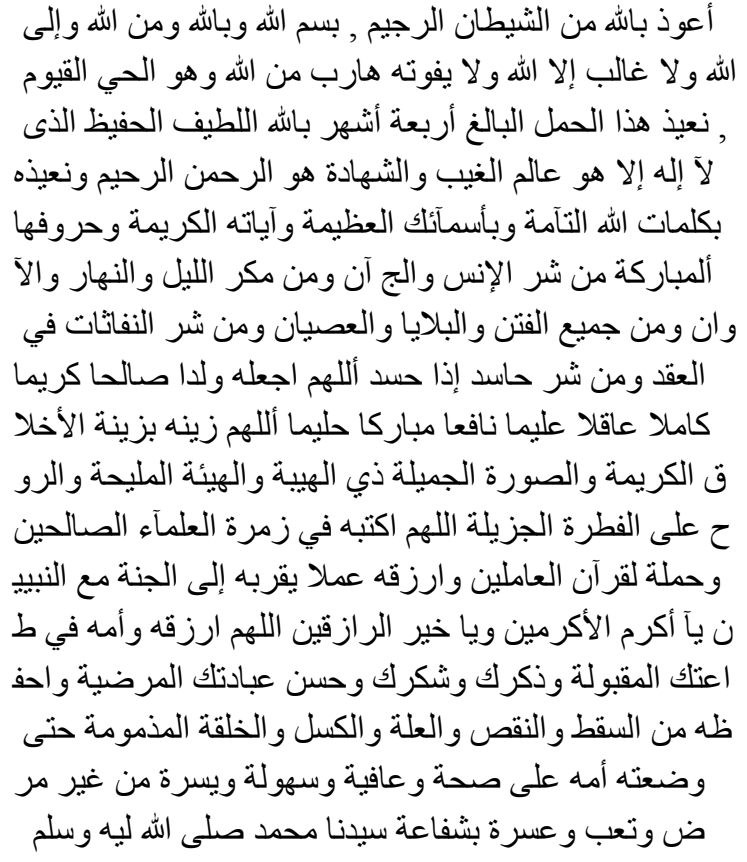

Which means: "I take refuge in Allah from the temptations of the accursed Satan, by calling on the name of Allah, the Most Gracious, the Most Merciful. From Allah, to Allah, no one wins except Allah, nothing can run from Allah, He is Alive and Alone. We ask for protection for this 4-month-old fetus from Allah, the Gentle, the Most Guarded, and there is no god but He who is the All-Knower of the unseen and visible. $\mathrm{He}$ is most gracious, merciful. We ask for protection for this fetus in God's perfect sentences, His great asthma, His glorious verses, His blessed letters from the ugliness of humans and jinns, from the temptations of night, day, and time, and from all slander, plagues and immorality, and from the evil of witches who blow knots, and from the evil of those who envy when they envy. O God make him (the fetus) as a child who is pious, noble, perfect, sensible, pious, beneficial, blessed, and wise. O Allah, decorate him with noble and fine and beautiful moral decoration, have a sweet authority and behavior, and a holy and great spirit. O Allah, write his destiny as part of the pious scholars, memorizers and practitioners of the Qur'an who can bring it closer to heaven with the Prophets, O most noble Essence among those who are noble and the Best Gizqi Essence Providers. O Allah, give rizqi to him 
and his mother to be obedient received, to remember you, give thanks to you, and worship good to You. Keep him from miscarriage, deficiencies, disabilities, laziness, and despicable form until his mother gave birth in a healthy and healthy condition, easily, easily, without pain, distress, and fatigue. With the intercession of the Prophet Muhammad."

Thus, the Ngupati tradition carried out by the community after the entry of Islam into Indonesia underwent a culture of culture and contained Islamic values.

Pregnancy Tradition Ceremony "Ngapati" in the Perspective of the Qur'an

QS. At-tiin verse 4 explains that Man was created by God in the best of creation. [7] In the process of its creation humans come from earth quintessence (QS. Al-Mu'minun verse 12), dry land such as pottery (QS. Ar-rahman verse 14), and turab or a small substance (QS. Al-Hajj Ayat 5). Which then will serve as the quintessence of semen stored in $\mathrm{r}$ Ahim. The process of human creation from sperm into a lump of flesh is divided into four periods. First, the period of nuthfah (in the form of sperm). Second, the period 'alaqah (blood clots). Third, the period of mudghah (lump of meat), and Fourth, the last period after the spirit is blown into the body of the fetus. This is as explained in QS. Al-Mu'minun Verses 1214 and QS. Al-Alaq verse 2 as follows:

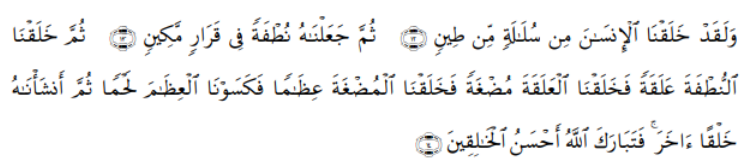

Which means: "12)" And verily we have created man from a essence (derived) from the ground ". 13) "Then we made the essence of semen (stored) in a firm place (the womb)". 14) "Then we made the lump of blood, and then made a lump of blood, and made a lump of flesh, and made the bones of the bones, and we wrapped the bones with flesh. Then we made him another (shaped) being. Then is Allah, the Most Good Creator " (Surah Al-Mu'minun: 12-14).

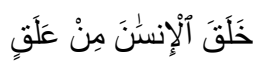

It means: "He has created man from a blood clot (QS. Al-Alaq: 2)."

The fetus experiences the development process in its mother's stomach in the following stages of development: First, before the age of four months, the fetus cannot be punished as a living human because the spirit has not been forgotten. If the fetus is released before the pregnancy is even four months old, it is not bathed, unconfined, and not nourished.

Second, after the womb is four months old, a spirit is blown to it. In this stage, the fetus has been punished as a living human being. If after that, the fetus comes out, then it must be bathed, dikfani, and halalat. Third, there are angels who are given the task of taking care of the womb (womb). Based on the words of the Prophet Muhammad, "Then sent an angel to him." Namely malalicate given the task to take care of the womb.

Fourth, the human condition is predestined when it is in the stomach of its mother, that is destined ri zki, charity, death and whether he is wretched or happy. Fifth, the explanation of the wisdom of God, that everything by its side is determined by a certain time limit with destiny; cannot be prioritized or terminated.

Sixth, everyone must feel fear and anxiety because the Messenger of Allah has reminded, "that a person works with the practice of a heavenly expert until the distance between himself and heaven is only one cubit, then he is preceded by destiny, so he acts with the practice of a hell expert, so he enters it."

Seventh, a human should not despair of the mercy of Allah SWT, because someone who performs deeds of disobedience in the time that Allah then Allah gives guidance to him, so he can get guidance and Husnul Khotimah at the end of his life. [8] 
This shows that the implicit meaning of God that events pence up's spirit in the newborn baby is an event of tremendous need to contemplate. And the Javanese people filled it with the tradition of the regent as part of the dhikr and Prayer to God for the safety of the pregnant woman and her baby. As well as food served as a form of alms.

Ceremony of the "Ngapati" Pregnancy Tradition in the Prophet's Hadith Perspective. The process of creating humans from sperm into lumps of meat as explained in the QS. AlMu'minun verses 12-14 require 120 days or 3 months which are divided into four periods, namely the nuthfah ( sperm) period for forty days, the 'alaqah (blood clots) period for forty days, the mudghah period (lumps of flesh) ) for forty days, and the last period after the spirit is blown into the body of the fetus.

In the fourth period, God sent an angel to blow his soul and set four things namely: sustenance, death, charity, and also accident or happiness. So that this is used as a basis for Muslims, especially the Javanese community to hold a slametan by reciting verses of the Koran,prayer and good prayers for the baby. Slametan when entering the fourth period of birth which also entered the fourth month of gestational age is what came to be known as "ngupati".

As explained in the following Hadith of the Prophet which later became the basis of Javanese society to continue implementing the tradition of ngupati :

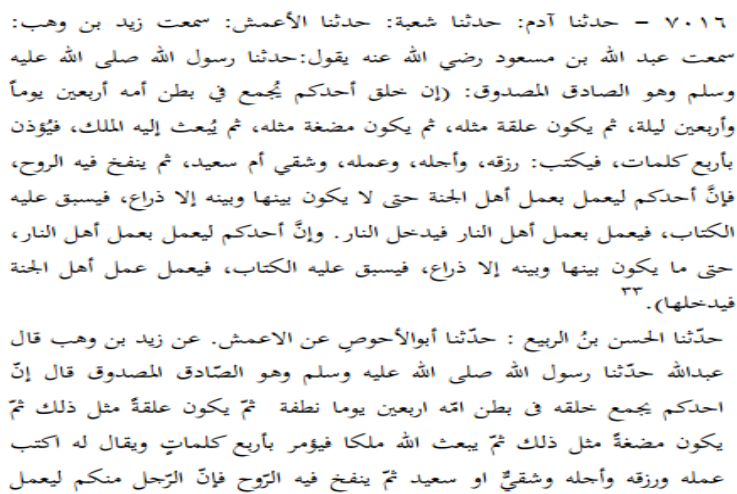

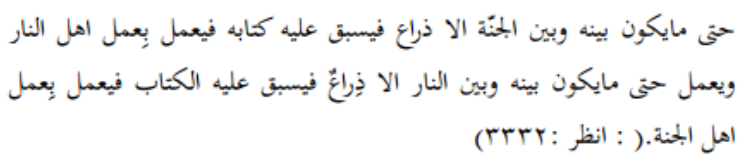

Which means: Surely each of you has been created in the stomach of the mother for 40 days in the form of a drop of semen. Then turned into a clot of blood for 40 days. Then it becomes a lump of meat for 40 days. After that an angel was sent to blow the spirit to him. The angel was also ordered to determine four things: his fortune, his death, his charity, and also accident or happiness. By Allah, there is no god but Him. Surely among you there are people who do charity like experts in heaven even the distance between him is only one cubit. However, the predetermined destiny is different, he did the deeds of hell until he went to hell. Surely there are some of you who do what an expert in hell does, even the distance between him and hell is only one cubit. However, the predetermined destiny is different, he did the deeds of heaven until he entered heaven ".

This shows the affirmation from the Messenger of Allāh bahwa that the head of the district is part of the Prophet that the Prophet gave to his people. Java community filled it with prayer and alms. Because alms is one of the loggers.

\section{CONCLUSION}

Based on the description above, it can be concluded that the tradition of ngupati carried out by the Javanese people is part of the implementation of the implied meaning of the Qur'an and Hadith.

The tradition of the pregnancy of the regent is an effort of the community which is filled with prayers, dhikr and devotion to beg for safety and blessings for pregnant women and their babies. 


\section{REFERENCES}

[1] Munawwir, 2000, Almunawwir Indonesian Arabic dictionary, Surabaya: Progesive Reader.

[2] A. Jamil, et al, 2002, Islam and Javanese culture, Jakarta: Gama Media.

[3] Clifford Geertz, 2014, Abangan Javanese Religion, Santri, Priyayi in Javanese Culture, Terj. Aswab Mahasin and Bur Rasuanto. Cet II, Depok: Bamboo Community.

[4] Suwito, 2007, Slametan and Javanese Cosmology: The Process of Islamic Acculturation with Javanese Culture in Ibda 'Journal, Purwokerto: P3M Stain Purwokerto.

[5] https://islam.nu.or.id/post/read/83033/doangupati-usia-kandungan-empat-bulan.

[6] Imam Abu 'Abdillah Muhammad Ibn Ismail Al-Bukhori, Shohih Bukhori, Beirut: Darul ibn Kathir, vol 6, pp. 2713

[7] QS. At-tin: 4

[8] http://www.babinrohis-nakertrans.org

[9] Purwadi, 2007, Encyclopaedia of Traditional Javanese Culture, Yogyakarta: Panji Reader.

[10] S. Suhandjati, 2015, Islam and Javanese Culture Revitalizing Local Wisdom, Semarang: Karya Abadi Jaya.

[11] T. Suliyati, Upacara Tradisi Masa Kehamilan dalam Masyarakat Jawa, Sabda: Jurnal Kajian Kebudayaan, 7(1).

[12] V. I. Maula, 2017, Praktek mapati dalam perspektif living hadis: studi kasus di Desa Harjowinangun Kec. Dempet Kab. Demak (Doctoral dissertation, UIN Walisongo).

[13] Adriana. Iswah 2012. NELONI. MITONI ATAU TINGKEBAN:(Pernaduan antara Tradisi Jawa dan Ritualitas Masvarakat Muslim). KARSA: Journal of Social and Islamic Culture, 19(2), 238-247.

[14] Bakker. JWM. Cultural Philosophy: an introduction, Kasinius Publisher, 1984

[15] http://www.jelajahbudaya.com 